\title{
설포닐유레아 최신지견
}

\section{김태년}

인제대학교 의과대학 해운대백병원 내분비대사내과

\section{Sulfonylurea, an Update}

\section{Tae Nyun Kim}

Division of Endocrinology and Metabolism, Department of Internal Medicine, Haundae Paik Hospital, Inje University College of Medicine, Busan, Korea

\begin{abstract}
Sulfonylureas (SUs) are widely prescribed in the treatment of type 2 diabetes. Despite the availability of several newer agents, SUs still play an important role in glucose-lowering therapy. However, over the last decade, there is a degrowth of older agents (SUs and thiazolidinediones) prescriptions with emergence of newer agents such as dipeptidyl peptidase-4 inhibitors, sodium glucose cotransporter-2 inhibitors and glucagon-like peptide-1 receptor agonists. The role of SUs in modern clinical practice poses ongoing clinical debate. With active marketing of these newer drugs, the concerns regarding hypoglycemia, secondary failure and cardiovascular safety tend to be overstated, especially when considering SUs. Some evidence has suggested that modern SUs (such as gliclazide modified release and glimepiride) have lower hypoglycemia and secondary failure rates and decreased risk of mortality from all-cause and cardiovascular disease compared to conventional SUs in patients with type 2 diabetes. Appropriate clinical judgement coupled with a patient-centered approach is crucial to achieve the best outcome in patients with type 2 diabetes. Modern SUs should also be considered based on their safety, efficacy, and low cost when choosing anti-hyperglycemic agents.
\end{abstract}

Keywords: Cardiovascular diseases; Diabetes mellitus, type 2; insulin secretion

\section{Corresponding author: Tae Nyun Kim}

Division of Endocrinology and Metabolism, Department of Internal Medicine, Haeundae Paik Hospital, Inje University College of Medicine, 875 Haeun-daero, Haeundae-gu, Busan 48108, Korea, E-mail: kimtn031वgmail.com

Received: May 26, 2021; Accepted: Jun. 9, 2021

This is an Open Access article distributed under the terms of the Creative Commons Attribution Non-Commercial License (http://creativecommons.org/licenses/by$\mathrm{nc} / 4.0 /$ ) which permits unrestricted non-commercial use, distribution, and reproduction in any medium, provided the original work is properly cited.

Copyright (c) 2021 Korean Diabetes Association 


\section{서론}

인슐린 발견 이후 100 년 동안 당뇨병의 병태생리에 대한 이 해가 깊어졌으며, 다양한 종류의 당뇨병 약제들이 개발되고 있다. 2형당뇨병은 인슐린저항성과 함께 췌장의 베타세포 기 능부전 등으로 인한 고혈당증으로 인해 발생하는 만성 진행 성 질병이며, 당뇨병 환자의 $90 \%$ 가 이에 해당한다[1,2]. 2형당 뇨병에 사용하는 경구혈당강하제는 작용기전에 따라 인슐린 분비를 촉진하는 약제와 인슐린 작용을 개선시키는 약제, 그 리고 인슐린 작용과는 독립적으로 혈당을 낮추는 약물들로 구분할 수 있다[3]. 설포닐유레아(sulfonylurea, SU)는 수십 년간 당뇨병 치료분야에서 중요한 역할을 차지하고 있고 여 전히 전 세계적으로 많이 사용하고 있는 인슐린 분비제이다. 국내에서도 대한당뇨병학회에서 발표한 Diabetes fact sheet 에 따르면, 비록 2제요법 환자들 중에 DPP-4 (dipeptidy1 peptidase-4) 억제제와 메트포민 조합이 가장 많은 부분을 차지하지만 $35 \%$ 환자는 여전히 설포닐유레아를 복용하고 있 을 정도로 설포닐유레아는 현재도 다양한 당뇨병 약제조합 에서 광범위하게 사용하고 있는 약제이다[4]. 하지만, 최근에 는 베타세포 기능을 유지하면서 혈당을 장기간 유지하고 저 혈당과 체중증가와 같은 부작용이 적은 새로운 기전의 약제 들(인크레틴 치료와 sodium glucose cotransporter [SGLT]-2 억제제)이 소개되면서 설포닐유레아는 장점보다는 부작용과 이차치료실패(secondary failure) 등 제한점들이 주로 부각되 어 왔다. 설포닐유레아와 관련한 저혈당과 체중증가와 같은 부작용과 심혈관에 대한 효과를 평가한 연구들은 현재는 거 의 사용하고 있지 않는 과거의 설포닐유레아 약제들이 포함 되어 수행했거나 결과가 연구들마다 상이하게 나오는 경우가 많았다[5]. 현재 국내에서 주로 사용하고 있는 글리클라자이 드, 글리클라자이드 modified release (MR)과 글리메피라이 드를 포함한 최신의 설포닐유레아(modern sulfonylurea)는 과거의 설포닐유레아와 비교해 부작용이 적고, 심혈관 이슈에 관해서도 안전성이 확보되고 있다.
역사

합성 설파 화합물의 혈당감소효과는 1937년 Ruiz 등에 의 해 알려졌다. 이후 1942년 프랑스 몽펠리에대학의 MJ Janbon 과 그 동료들이 장티푸스(typoid) 치료제로 개발한 설파계열 의 항생물질인 $p$-amino-sulfonamide-isopropylthiodiazole 이 저혈당을 유발시킨다는 것을 확인하였다. 1946년에는 Lovatieres 등은 이러한 약물들이 췌장의 베타세포를 자극하 여 인슐린을 분비한다는 것을 밝혔다[6]. 1955년 독일의 베링 거사는 베타세포 촉진 작용이 있는 당뇨병 치료제를 발표하 였고, 2형당뇨병 치료의 초석 역할을 해오고 있는 설포닐유 레아는 비로소 1956년에 톨부타마이드(tolbutamide)가 발매 된 이후에 클로르프로파마이드(chlorpropamide), 아세토헥 사마이드(acetohexamide) 및 톨라자마이드(tolazamide) 등 이 1 세대 약제로 소개되었다. 이후로 발매된 글리벤클라마이 드(glibenclamide), 글리부라이드(glyburide), 글리클라자이드 (gliclazide), 글리피자이드(glipizide), 글리퀴돈(gliquidone)을 2세대로 구분할 수 있다[7]. 글리메피라이드(glimepiride)는 1995년에 미국에서 소개되었다. 현재 국내에서는 1990년대 이 후 1 세대 약물과 글리벤클라마이드 사용이 감소되고, 글리메 피라이드와 글리클라자이드가 주로 사용되고 있다.

\section{분류}

설포닐유레아는 개발순서 또는 작용시간을 기준으로 다 양한 카테고리로 분류할 수 있을 것이다. 작용시간을 기 준으로 분류해보면, 속효성으로는 톨부타마이드, 중간형 은 글리피자이드, 글리클라자이드, 그리고 장시간형은 글리 벤클라마이드, 글리메피라이드, 글리클라자이드 $\mathrm{MR}$ 과 글 리피자이드 MR로 나눌 수 있다. 개발순으로 보면 3세대 로 불리는 글리메피라이드와 글리클라자이드, 글리클라자이 드 MR을 modern SUs로, 글리벤클라마이드와 이전 1세대를 conventional SUs로 나눌 수 있다[8]. 설포닐유레아는 그 세 대, 작용시간 그리고 여러 약역학/약동학에 따라 Table 1과 같이 분류할 수 있다[9]. 
Table 1. Various generations of sulfonylureas

\begin{tabular}{|c|c|c|c|c|}
\hline Sulfonylurea & Trade name & $\begin{array}{l}\text { Daily dose range } \\
(\mathrm{mg})\end{array}$ & $\begin{array}{l}\text { Duration of action } \\
\text { (h) }\end{array}$ & $\begin{array}{c}\text { Elimination } \\
\text { (urine) \% }\end{array}$ \\
\hline \multicolumn{5}{|l|}{ Generation I } \\
\hline Tolbutamide & Tolbutamide & $500 \sim 2,000$ & $6 \sim 10$ & 100 \\
\hline Chlorpropamide & Diabinese & $50 \sim 500$ & $26 \sim 60$ & $80-90$ \\
\hline Tolazamide & Tolazamide & $100 \sim 1,000$ & $12 \sim 24$ & 85 \\
\hline \multicolumn{5}{|l|}{ Generation II } \\
\hline Glibenclamide $^{a}$ & Daonil & $2.5 \sim 30$ & $20 \sim 24$ & 50 \\
\hline Glipizide $^{\mathrm{a}}$ & Glibenese, Minodiab & $2.5 \sim 40$ & $14 \sim 16$ & 80 \\
\hline Gliclazide $^{\mathrm{a}, \mathrm{b}}$ & Diamicron & $40 \sim 320$ & $16 \sim 24$ & $60-70$ \\
\hline Gliclazide $\mathrm{MR}^{\mathrm{a}, \mathrm{b}}$ & Diamicron MR & $30 \sim 120$ & $>24$ & $60-70$ \\
\hline Glimepiride $^{\mathrm{a}, \mathrm{b}}$ & Amaryl & $1 \sim 8$ & $>24$ & 60 \\
\hline
\end{tabular}

MR, modified release.

${ }^{\mathrm{a}}$ Commercially available drug in Korea. ${ }^{\mathrm{b}}$ Modern sulfonylurea

Adapted from Diabetes. 5th ed. Seoul: Panmun Education; 2018. p390 [9].

\section{Mordern 설포닐유레아}

\section{1. 글리클라자이드, 글리클라자이드 MR}

소화관에서 거의 완전히 흡수되어 2 6시간에 최고 혈중 농 도에 도달한다. 혈중 반감기는 10 시간 정도이며 작용시간은 16 24시간 지속된다. 간에서 대부분 불활성물질로 대사되어 소변으로 70\%, 담즙으로 30\%가 배설된다. 1980년대 후반 부터 국내에서 사용되어 왔으며, 2000년대 초 하루 종일 서 서히 분비되어 흡수되는 새로운 제형인 글리클라자이드 $\mathrm{MR}$ 이 출시되었다. 이 약제는 식전, 식후 고혈당에 모두 효과가 있으며, 야간 저혈당의 빈도를 줄일 수 있는 장점이 있다. 글 리클라자이드는 근육의 인슐린민감성 증가와 혈소판응집 억 제효과가 보고되고 있다. 글리클라자이드는 초회 용량으로 40 80 mg을 사용하며 최대 용량은 $320 \mathrm{mg}$ 이다. 글리클라 자이드 $\mathrm{MR}$ 은 초회 용량으로 $30 \mathrm{mg}$ 을 사용하며 최대 용량 은 $120 \mathrm{mg}$ 까지 사용할 수 있다. 신기능이나 간기능 저하 환
자에게도 사용가능한 약제이며, 특히, 투석환자에 있어서도 저용량으로 모니터링하면서 사용가능한 약제이다. 체중증가 와 저혈당과 같은 부작용은 다른 설포닐유레아 약물들에 비 해 정도와 빈도가 낮은 것으로 알려져 있다[9].

\section{2. 글리메피라이드}

1990년대 후반부터 우리나라에서 사용되고 있는 설포닐유 레아다. 간에서 대사되어 소변으로 $60 \%$, 대변으로 $40 \%$ 배설 된다. 저혈당 위험은 1 세대 설포닐유레아나 클리벤클라마이 드보다 유의하게 낮으며, 작용시간이 길어 하루에 한번 복용 하며, 단위무게 당 효능을 비교할 경우 설포닐유레아 가운데 가장 강력한 혈당강하효과가 있어 현재 한국에서 가장 많이 사용하고 있는 설포닐유레아다. 일부 설포닐유레아는 심근의 ATP-의존성 칼륨통로(ATP-sensitive potassium channels, $\mathrm{K}_{\mathrm{ATP}}$ 통로)에도 작용하여 심근 허혈 시 나타나는 심근보호 현상을 저해하여 심근경색의 크기를 악화시킨다고 알려져 있 
다. 이에 비해 글리메피라이드는 췌장 설포닐유레아수용체 (sulfonylurea receptor, SUR)에 대한 선택성이 높고, 1세대 설 포닐유레아나 2세대 중의 글리벤클라마이드보다 심혈관계 부 작용이 적은 것으로 나타났다. 초회 용량으로 1 2 mg을 투 여하고 유지용량으로 1 4 mg, 최대 용량은 $8 \mathrm{mg}$ 까지 사용 가능하다. 만성콩팥병 3기 이상인 경우에서는 $1 \mathrm{mg}$ 의 저용량 으로 시작해서 서서히 증량이 가능하며, 투석 환자에 있어서 는 사용할 수 있으나 저용량으로 모니터링하면서 사용해야 한다[9].

\section{작용기전과 효과}

설포닐유레아는 인슐린분비촉진제로 분류하고 있으며, 췌 장 베타세포에서 인슐린 분비를 자극함으로써 혈당강하 작 용을 나타낸다. 췌도 베타세포막에 있는 ATP-의존성 칼륨 통로 $\left(\mathrm{K}_{\mathrm{ATP}}\right.$ 통로 $)$ 의 $\mathrm{SUR}$ 에 설포닐유레아가 결합하면 $\mathrm{K}_{\mathrm{ATP}}$ 통 로가 차단되어 $\mathrm{K}^{+}$의 세포 밖 유출이 억제되고, 세포 내로는 $\mathrm{Ca}^{2+}$ 이 유입되어 세포 내 농도가 증가된다. 증가된 세포 내 $\mathrm{Ca}^{2+}$ 은 칼모듈린(calmodulin)과 결합하여 인슐린 과립을 세 포표면으로 이동시켜 인슐린 분비를 촉진시킨다. $\mathrm{K}_{\mathrm{ATP}}$ 통로 는 독립된 두 종류의 단백질(subunit)로 구성되는데, 하나는 SUR이고 다른 하나는 칼륨 통로자체를 구성하는 Kir6.x 단 백질로 구성된다. 조직특이적 $\mathrm{K}_{\mathrm{ATP}}$ 통로는 각각의 유전자들 에 의해 Kir6.1 또는 6.2로 나타나는데, 통로의 조직마다의 차이는 Kir6.x와 SUR 단백질의 조합에 따라 결정되게 된다. 예를 들어, 췌장의 베타세포에서는 Kir6.2/SUR1이, 심장 근육 세포에서는 Kir6.2/SUR2A와 SUR2B로 구성된다. 설포닐유 레아 계열에서 각각의 약물들은 각 조직특이성 $\mathrm{K}_{\mathrm{ATP}}$ 통로를 구성하고 있는 SUR과 Kir6.x에 친화도와 가역적인 결합정도 의 차이를 보여주었다. 이러한 차이가 설포닐유레아 계열의 각 약물의 효과, 이차치료실패, 그리고 심혈관질환의 안전성 결과 에도 영향을 끼쳤을 가능성이 있다[10].

설포닐유레아는 초기의 당화혈색소 감소와 비용 측면에서 매우 우수한 효과를 가지고 있음은 부인할 수 없는 사실이 다. 체계적 문헌고찰과 메타분석 결과를 보더라도, 설포닐유
레아는 단독사용 시 위약 대비 당화혈색소 $1.51 \%$ 감소효과 가 있는 것으로 나타났고, 다른 경구혈당강하제에 추가하더 라도 다른 약제치료에 비해 $1.62 \%$ 감소효과가 있었다[11]. 흥 미로운 사실은 고용량의 설포닐유레아가 저용량에 비해 통계 적으로 큰 당화혈색소 감소효과는 보여주지 못하였다. 모든 설포닐유레아는 간과 신장에 의해 배설되며, 대부분의 성인 환 자들에게 좋은 내약성을 가지고 있다. 저혈당과 체중증가는 잘 알려진 설포닐유레아 사용의 대표적인 장애요소이다.

\section{설포닐유레아의 안전성 이슈}

전 세계적으로 처음 진단받은 2 형당뇨병 환자에게는 메트 포민을 일차약제로 권고하고 있다. 하지만 메트포민으로 목 표혈당에 도달하지 못한 경우에 2차 약제를 추가하는 데 있 어서는 가이드라인마다 상이한 점이 있었다[12]. SGLT-2 억제 제나 GLP-1수용체작용제(glucagon-like peptide-1 receptor agonist)와 같은 약제는 대규모 심혈관질환 outcome 연구결 과를 바탕으로 동맥경화성 심혈관질환이 있는 2형당뇨병 환 자에게 2차 약제로 우선 권고하는 것을 최근 가이드라인들에 서 반영 중에 있다[13,14]. 이에 비해 설포닐유레아는 미국 당 뇨병학회와 유럽의 당뇨병과 심장학회에서 심혈관질환이 없는 환자에서 비용측면에서 2차 약제로 고려될 수 있으나 이 외에 있어서는 다른 경구약제를 먼저 고려 후 5 번째 정도의 순서로 우선순위에서 한참 밀려나 있다[14,15]. 최근의 outcome 기반 의 치료접근 가이드라인들은 새로운 약제들의 중요성은 부 각할 수 있으나 상대적으로 설포닐유레아 같이 오랜 기간 잘 입증되어 온 해당약제의 효과와 안전성을 무시하거나 편견을 낳을 수도 있을 것이다. 또한, 설포닐유레아는 다른 약제들 에 비해 높은 혈당감소를 보이는 class 효과를 가지기도 하 지만 약리적 특성이 다르므로 임상적으로 다른 안전성 결과 를 보여주기도 하였다. 설포닐유레아도 다른 경구혈당강하제 와 마찬가지로 편견 없이 약제가 가지는 임상적인 이익, 환자 의 삶의 질, 안전성, 비용 등을 종합적으로 평가하여 사용되 어야 할 것이다. 


\section{1. 설포닐유레아와 심혈관질환}

1970년대에 당뇨병 임상연구에서는 첫 번째 무작위 대조연 구(randomized control trial, RCT) 중 하나인 UGDP (The University Group Diabetes Program)가 있었다. 200명 의 환자를 인슐린군, tolbumtamide군 또는 위약으로 무작 위 배정하여 연구가 진행되었고 추후에 phenformin군이 생 겼다. Tolbumtamide군은 조기종료가 되었는데, 위약 대비 사망률이 증가했기 때문이었다( $12.7 \%$ vs. $4.9 \%$ in placebo arm). 또한, 인슐린군에 비해 심혈관 사건의 위험도 높은 것 으로 나타났다. UGDP 연구는 연구디자인과 연구수행에 있 어 많은 문제점이 제기되었지만, 설포닐유레아의 안전성에 관 한 논란을 불러일으키기에는 충분하였다. UGDP 연구결과 는 UKPDS (The UK Prospective Diabetes Study) 연구가 수행되는 촉매가 되었다. UKPDS 연구결과 2형당뇨병 환자 에서 설포닐유레아는 심혈관질환에 의한 사망, 심근경색 또 는 급작스런 사망 위험을 증가시키지 않았다[5]. TOSCA. IT (Thiazolidinediones Or Sulfonylureas Cardiovascular Accidents Intervention Trial)은 설포닐유레아의 심혈관질환 안전성에 대한 근거를 더해 준 연구로 당시에 주로 사용하 던 pioglitazone 군( $\mathrm{n}=1,535)$ 과 설포닐유레아 군( $\mathrm{n}=1,493$, $2 \%$ glibenclamide, $48 \%$ glimepiride, $50 \%$ gliclazide)으로 무작위 배정하여 진행하였다[16]. 연구결과에서 저혈당 빈도 는 설포닐유레아군에서 높게 나타났으나(508 [34\%] vs. 148 [10\%], $P$ < 0.0001), 일차 목표인 심혈관질환의 발생에는 양 군 간에 차이는 없었다(hazard ratio 0.96, 95\% confidence interval [CI] 0.74 1.26, $P=0.79$ ).

대규모 메타분석들에서도 설포닐유레아의 심혈관질환 안전 성 결과는 다소 상이하게 나타났다[17,18]. 이들 메타분석을 무작위대조시험과 관찰연구로 나누어 분석했을 때, 72 개 무 작위대조시험만을 메타분석한 결과에서 설포닐유레아는 위 약뿐만 아니라 메트포민과도 사망위험에 차이가 나지 않았 다. 1 세대와 나누어서 분석한 결과에서는 2 세대 설포닐유레 아는 위약과 비교하여 심혈관 사망위험에 차이가 없었으나, 1 세대 설포닐유레아 약물들로 분석했을 때는 심혈관 사망 위
험이 높게 나타났다(relative ratio 2.63, 95\% CI 1.32 5.22, $P=0.006)$ [10]. 관찰연구에서는 메트포민과 비교하여 심혈 관질환 발생위험이 높게 나타났으나, 앞의 TOSCA.IT 이후 의 대규모 RCT에서는 설포닐유레아가 심혈관질환의 위험을 올리지는 않는 것으로 나타났다. 대표적으로 CAROLINA (The Cardiovascular Outcome Study of Linagliptin vs Glimepiride in Type 2 Diabetes) 연구는 글리메피라이드 와 $\mathrm{DPP}-4$ 억제제인 리나글립틴 간의 주요 심혈관질환 사건 발생률의 차이가 없음을 보여주었다[19]. ADVANCE (The Action in Diabetes and Vascular Disease: Preterax and Diamicron MR Controlled Evaluation) 연구는 55세 이상인 2형당뇨병 환자를 대상으로 글리클라자이드를 이용하여 철 저한 혈당조절 치료군과 표준 치료군으로 분류했다. 철저한 혈당조절군은 평균 당화혈색소를 $6.5 \%$ 까지 안전하게 조절 했고 주요 대혈관질환 합병증과 미세혈관질환 합병증에 대한 복합 종말점에서 위험을 $10 \%$ 감소시켰다. 심혈관질환으로 인 한 사망위험은 통계적으로 유의하지는 않으나 $12 \%$ 정도 감 소시켰고 철저한 혈당조절 치료가 사망의 위험을 높인다는 증거는 없었다[20].

현재 국내에서 주로 사용하고 있는 modern 설포닐유레아 인 글리메피라이드와 글리클라자이드는 1세대 SU와 글리벤클 라마이드보다 전체사망률과 심혈관사망률이 낮다고 보고되 고 있는데[21], 이는 modern SU가 췌장 베타세포 SUR1에는 높은 친화력을 보이고 심장과 혈관평활근세포 SUR2에는 작 용하지 않는 것으로 보이며, 다른 설포닐유레아에 비해 저혈 당 발생이 낮기 때문인 것으로 설명된다.

\section{2. 설포닐유레아와 중증저혈당}

설포닐유레아는 일반적으로 내약성이 좋고, 부작용 빈도 가 낮은 약제이다. 저혈당은 설포닐유레아 사용 시 가장 흔 히 발생되는 부작용이다. 중증저혈당은 사망 위험 증가와 관 련이 있어 보이나, 인과관계는 증명해내지 못하고 있는 실정이 다[22]. 대체로 중증 저혈당 자체가 동반질환의 지표 또는 질 환의 중증도를 반영하는 표지자로 설명하기도 한다. 무작위 
대조시험의 결과에 있어서는 비록 중증저혈당 빈도의 차이가 있지만 심혈관질환 발생위험이나 사망률 증가와는 관련이 없 는 경우가 많았다[16,23]. 몇몇 관찰연구에서는 설포닐유레아 사용을 하더라도 중증저혈당 발생은 비교적 드물게 나타난 다라고 보고하였다[24,25]. 게다가, 설포닐유레아 약물 간에 도 저혈당 위험도는 다양하게 나타나는데, 가장 최근의 메타 분석 결과에 따르면 가장 위험도가 낮은 약물은 글리클라자 이드로 비교 위험도는 위약대비 3.9였고, 이는 메트포민이 2.0 이라는 점에서 메트포민과 유사한 정도의 위험도로 나타났 다. 그 뒤를 이어서 글리메피라이드가 8.9, 다음이 글리부라이 드 10.2, 글리피자이드 13.9 순이었다[26]. 저혈당 위험은 고령 환자 또는 노쇠한 환자, 중증의 신장, 간 혹은 심혈관질환 환 자에서 증가할 수 있다. 이러한 환자에게는 목표혈당을 조정 하고, 되도록 설포닐유레아 사용을 피해야 하겠으나, 사용해 야 할 경우 저용량으로 반드시 시작해서 2 4주간의 간격으 로 약물용량을 조절해야 한다.

\section{3. 설포닐유레아와 체중증가}

체중과 관련하여 최근의 가이드라인은 체중증가를 유발 할 수 있는 설포닐유레아나 싸이아졸리딘다이온보다는 체 중감소와 관련이 있는 SGLT-2 억제제와 GLP-1수용체작용 제와 같은 새로운 당뇨병 약제를 더 추천하고 있다[26]. 임 상시험에서 SGLT-2 억제제는 최대용량에서 평균 체중감소 가 $1.5 \sim 2.4 \mathrm{~kg}$ 으로, GLP-1수용체작용제는 $0.9 \sim 1.8 \mathrm{~kg}$ 정도 로 나타났다. 반면에 UKPDS 연구결과 식이 치료군에 비해 설포닐유레아(글리벤클라마이드나 클로르프로파마이드)군에 서 1.7 2.6 kg의 체중증가가 있었다. 체중증가는 초기 3 4년 에 발생하며, 이후에는 증가하지 않았다. 그러나 현재 국내에 서 사용하고 있는 modern SU는 체중증가가 매우 적은 것으 로 알려져 있는데, 특히 ADVANCE 연구에서 사용한 글리클 라자이드 $\mathrm{MR}$ 은 5 년간의 연구기간 동안 체중증가가 없는 것 으로 나타났다[20].

\section{4. 설포닐유레아와 치료실패}

설포닐유레아의 장기치료 시 낮은 치료 지속률에 대한 우 려가 있어 왔다. 비록 UKPDS에서 베타세포의 기능이 식사 요법, 메트포민 치료군 및 설포닐유레아군 모두에게 같은 비 율로 감소하는 것으로 밝혀졌으나, $\mathrm{ADOPT}$ (A Diabetes Outcome Progression Trial) 연구에서는 설포닐유레아군 이 메트포민이나 로시글리타존에 비해 빠른 치료실패를 보여 주었고 누적 실패율 또한 가장 높았다(5년간 로시글리타존 $15 \%$, 메트포민 21\%, 글리부라이드 34\%) [27]. 설포닐유레아 의 이차치료실패를 뒷받침하는 가설로는 먼저 $\mathrm{K}_{\mathrm{ATP}}$ 통로의 지 속적인 닫힘으로 베타세포사멸이 초래되어 발생한다는 비가 역적 가설이 있다. 다른 가설로는 베타세포 사멸없이 지속적 인 $\mathrm{K}_{\mathrm{ATP}}$ 통로의 닫힘으로 인슐린 분비 장애가 악화될 수 있고 다시 설포닐유레아를 중단하면 가역적으로 인슐린분비기능이 회복될 수 있다는 것이다. 첫 번째 근거로는 배양된 췌도세포 에 글리벤클라마이드(0.1 10 $\mu \mathrm{mol})$, 나테글리니드(10 $\mu \mathrm{mol})$ 와 레파글리니드(0.01 1 $\mu \mathrm{mol})$ 를 노출하였을 때 글리벤클라마이 드에서만 베타세포 사멸이 증가하였다는 것이다[28]. 후자의 경우, 실험실 연구에서 야생 생쥐에 글리벤클라마이드를 서서 히 노출했을 때 만성적인 $\mathrm{K}_{\mathrm{ATP}}$ 통로의 닫힘이 유도되었고 점 차적으로 고혈당에 대한 인슐린 분비가 감소되는 것이 관찰 되었다. 글리벤클라마이드 노출을 중단하고 1개월 내에 인슐 린 분비능이 개선되는 것이 보였고 이후 조직검사에서도 베타 세포사멸은 관찰되지 않았다[10]. 하지만 사람에 있어서는 이 차치료실패의 정확한 원인은 아직 규명되어 있지 않고, 치료 반응과 이차치료실패도 매우 다양하게 나타난다. 다른 치료 법 대비 설포닐유레아의 치료실패를 보여준 연구들도 있지만, 당뇨병을 처음 진단받은 환자들을 대상으로 한 UKPDS 연 구에서는 베타세포의 기능이 식사요법군, 메트포민 치료군 및 설포닐유레아 치료군 모두에게 같은 비율로 감소하는 것으 로 나타났다. 현재 주로 사용하고 있는 modern 설포닐유레 아는 다른 약제에 비해 낮은 이차실패율을 보여주었다. 


\section{결론}

설포닐유레아의 혈당감소효과의 발견 이후 최초의 당뇨병 치료제로서 발표한 지도 벌써 60년의 세월이 흘렀다. 현재까 지도 설포닐유레아는 혈당조절 관리에 있어 매우 중요한 역 할을 하고 있는 치료제이다. 하지만, 최근의 새로운 약물이 소개되면서 오랜 기간 설포닐유레아에 제기되어 온 체중증가, 저혈당, 이차치료실패, 그리고 심혈관 안전성 이슈가 과도하 게 제기된 측면이 있다. 현재 주로 사용하고 있는 글리클라자 이드와 글리메피라이드는 과거의 설포닐유레아에 비해 혈당 조절, 저혈당과 이차치료실패에서 개선된 결과를 보여주었고, 심혈관 안전성 논란도 대규모 무작위대조시험 결과들에 의해 점차적으로 해소되고 있다. 설포닐유레아는 복용법이 편리하 고 저렴하며, 오랜 역사를 가지고 있어 부작용 또한 예측이 가능한 장점을 가지고 있다. 향후 설포닐유레아에 대해 입증 된 유효성 및 안정성을 바탕으로 편견없이 처방되기를 기대한 다.

\section{REFERENCES}

1. Butler AE, Janson J, Bonner-Weir S, Ritzel R, Rizza RA, Butler PC. Beta-cell deficit and increased betacell apoptosis in humans with type 2 diabetes. Diabetes 2003;52:102-10.

2. World Health Organization. Diabetes fact sheet. No. 312. Geneva: World Health Organization; 2009.

3. Bressler R, Johnson DG. Pharmacological regulation of blood glucose levels in non-insulin-dependent diabetes mellitus. Arch Intern Med 1997;157:836-48.

4. Korean Diabetes Association. Diabetes fact sheet in Korea 2018. Seoul: Korean Diabetes Association; 2018.

5. Intensive blood-glucose control with sulphonylureas or insulin compared with conventional treatment and risk of complications in patients with type 2 diabetes (UKPDS 33). UK Prospective Diabetes Study (UKPDS) Group.
Lancet 1998;352:837-53.

6. Levine R. Sulfonylureas: background and development of the field. Diabetes Care 1984;7 Suppl 1:3-7.

7. Kreisberg RA. The second-generation sulfonylureas: change or progress? Ann Intern Med 1985;102:125-6.

8. Kalra S, Aamir AH, Raza A, Das AK, Azad Khan AK, Shrestha $\mathrm{D}$, et al. Place of sulfonylureas in the management of type 2 diabetes mellitus in South Asia: a consensus statement. Indian J Endocrinol Metab 2015;19:577-96.

9. Korean Diabetes Association. Diabetes. 5th ed. Seoul: Panmun Education; 2018. p389-94.

10. Cordiner RLM, Pearson ER. Reflections on the sulphonylurea story: a drug class at risk of extinction or a drug class worth reviving? Diabetes Obes Metab 2019;21:761-71.

11. Hirst JA, Farmer AJ, Dyar A, Lung TW, Stevens RJ. Estimating the effect of sulfonylurea on $\mathrm{HbAlc}$ in diabetes: a systematic review and meta-analysis. Diabetologia 2013;56:973-84.

12. Khunti K, Hassanein M, Lee MK, Mohan V, Amod A. Role of Gliclazide MR in the management of type 2 diabetes: report of a symposium on real-world evidence and new perspectives. Diabetes Ther 2020;11(Suppl 2):33-48.

13. Diabetes Canada Clinical Practice Guidelines Expert Committee, Stone JA, Houlden RL, Lin P, Udell JA, Verma S. Cardiovascular protection in people with diabetes. Can J Diabetes 2018;42 Suppl 1:S1-325.

14. Cosentino F, Grant PJ, Aboyans V, Bailey CJ, Ceriello A, Delgado V, et al. 2019 ESC Guidelines on diabetes, pre-diabetes, and cardiovascular diseases developed in collaboration with the EASD. Eur Heart J 2020;41:255323.

15. Davies MJ, D'Alessio DA, Fradkin J, Kernan WN, Mathieu C, Mingrone G, et al. Management of hyperglycaemia 
in type 2 diabetes, 2018. A consensus report by the American Diabetes Association (ADA) and the European Association for the Study of Diabetes (EASD). Diabetologia 2018;61:2461-98.

16. Vaccaro O, Masulli M, Nicolucci A, Bonora E, Del Prato S, Maggioni AP, et al. Effects on the incidence of cardiovascular events of the addition of pioglitazone versus sulfonylureas in patients with type 2 diabetes inadequately controlled with metformin (TOSCA. IT): a randomised, multicentre trial. Lancet Diabetes Endocrinol 2017;5:887-97.

17. Monami M, Genovese S, Mannucci E. Cardiovascular safety of sulfonylureas: a meta-analysis of randomized clinical trials. Diabetes Obes Metab 2013;15:938-53.

18. Azoulay L, Suissa S. Sulfonylureas and the risks of cardiovascular events and death: a methodological metaregression analysis of the observational studies. Diabetes Care 2017;40:706-14.

19. Rosenstock J, Kahn SE, Johansen OE, Zinman B, Espeland MA, Woerle HJ, et al. Effect of linagliptin vs glimepiride on major adverse cardiovascular outcomes in patients with type 2 diabetes: the CAROLINA randomized clinical trial. JAMA 2019;322:1155-66.

20. ADVANCE Collaborative Group, Patel A, MacMahon S, Chalmers J, Neal B, Billot L, et al. Intensive blood glucose control and vascular outcomes in patients with type 2 diabetes. N Engl J Med 2008;358:2560-72.

21. Simpson SH, Lee J, Choi S, Vandermeer B, Abdelmoneim AS, Featherstone TR. Mortality risk among sulfonylureas: a systematic review and network meta-analysis. Lancet Diabetes Endocrinol 2015;3:43-51.
22. International Hypoglycaemia Study Group. Hypoglycaemia, cardiovascular disease, and mortality in diabetes: epidemiology, pathogenesis, and management. Lancet Diabetes Endocrinol 2019;7:385-96.

23. Rosenstock J, Perkovic V, Johansen OE, Cooper ME, Kahn SE, Marx N, et al. Effect of linagliptin vs placebo on major cardiovascular events in adults with type 2 diabetes and high cardiovascular and renal risk: the CARMELINA randomized clinical trial. JAMA 2019;321:69-79.

24. Shorr RI, Ray WA, Daugherty JR, Griffin MR. Incidence and risk factors for serious hypoglycemia in older persons using insulin or sulfonylureas. Arch Intern Med $1997 ; 157: 1681-6$.

25. Dunkley AJ, Fitzpatrick C, Gray LJ, Waheed G, Heller SR, Frier BM, et al. Incidence and severity of hypoglycaemia in type 2 diabetes by treatment regimen: a UK multisite 12-month prospective observational study. Diabetes Obes Metab 2019;21:1585-95.

26. Maloney A, Rosenstock J, Fonseca V. A model-based meta-analysis of 24 antihyperglycemic drugs for type 2 diabetes: comparison of treatment effects at therapeutic doses. Clin Pharmacol Ther 2019; 105:1213-23.

27. Kahn SE, Haffner SM, Heise MA, Herman WH, Holman RR, Jones NP, et al. Glycemic durability of rosiglitazone, metformin, or glyburide monotherapy. N Engl J Med 2006;355:2427-43.

28. Maedler K, Carr RD, Bosco D, Zuellig RA, Berney T, Donath MY. Sulfonylurea induced beta-cell apoptosis in cultured human islets. J Clin Endocrinol Metab 2005;90:501-6. 